\title{
PEMBENTUKAN PORTOFOLIO OPTIMAL PADA SAHAM INDEKS IDX80 DENGAN MENGGUNAKAN MODEL MARKOWITZ
}

\author{
Ni Kadek Arista Dewi ${ }^{1}$ \\ Made Reina Candradewi ${ }^{2}$ \\ ${ }^{1,2}$ Fakultas Ekonomi dan Bisnis Universitas Udayana, Bali, Indonesia \\ email: aristadewi1998@gmail.com
}

\begin{abstract}
ABSTRAK
Tujuan penelitian ini untuk mengetahui saham-saham perusahaan yang masuk ke dalam portofolio optimal beserta besarnya proporsi dana akhir masing-masing saham perusahaan. Penelitian ini dilakukan di Bursa Efek Indonesia pada saham perusahaan yang termasuk indeks IDX80 periode Februari-September 2019. Penelitian ini menggunakan data sekunder dengan metode pengumpulan data observasi nonpartisipan. Sampel penelitian berjumlah 74 saham yang didapat melalui metode purposive sampling dengan teknik analisis data menggunakan model Markowitz. Hasil penelitian menunjukkan terdapat 7 saham yang layak menjadi anggota portofolio optimal model Markowitz pada saham indeks IDX80. Adapun ketujuh saham tersebut antara lain, ACES 11,458 persen, HOKI 2,539 persen, ICBP 26,947 persen, PWON 33,071 persen, TBIG 9,541 persen, WIKA 2,760 persen, dan WOOD 13,684 persen yang memberikan expected return portofolio sebesar 1,806 persen dengan tingkat risiko portofolio sebesar 0,705 persen.
\end{abstract}

Kata Kunci: investasi, portofolio optimal, indeks IDX80, model Markowitz

\begin{abstract}
The purpose of this study is to determine the company's shares that are included in the optimal portfolio along with the magnitude of the final fund proportion of each company's shares. This research was conducted at the Indonesia Stock Exchange on company shares that included the IDX80 index from February to September 2019. This study used secondary data with nonparticipant observation data collection methods. The research sample of 74 shares obtained through purposive sampling method with data analysis techniques using the Markowitz model. The results showed that there were 7 shares worthy of being members of the optimal portfolio of Markowitz models on IDX80 index shares. The seven shares included ACES 11.458 percent, HOKI 2.539 percent, ICBP 26.947 percent, PWON 33.071 percent, TBIG 9.541 percent, WIKA 2.760 percent, and WOOD 13.684 percent which gave an expected portfolio return of 1.806 percent with a portfolio risk of 0.705 percent.

Keywords: investment, optimal portfolio, IDX80 index, Markowitz model
\end{abstract}




\section{PENDAHULUAN}

Saat ini investor dihadapkan pada berbagai jenis investasi yang dapat dilakukan. Investasi dilakukan para investor bertujuan untuk mendapatkan return yang diharapkan. Investasi dalam istilah keuangan merupakan suatu aset bernilai moneter yang dibeli untuk menghasilkan return di masa depan (Rodrigues dan Suresha, 2018). Secara umum investasi merupakan komitmen investor untuk menjaga sejumlah dana yang dimiliki dengan harapan dapat memperoleh keuntungan yang maksimal di masa mendatang. Menginvestasikan dana pada aset riil seperti tanah, emas, mesin atau bangunan maupun aset finansial seperti deposito, saham atau obligasi merupakan aktivitas investasi yang umum dilakukan oleh investor (Tandelilin, 2010:2).

Investor dapat melakukan investasi aset finansial pada pasar modal. Pasar modal merupakan media bertemunya investor baik perorangan maupun kelompok yang memiliki kelebihan dana dengan perusahaan yang memerlukan dana pada berbagai jenis instrumen investasi yang menawarkan tingkat return dengan risiko yang berbeda (Wahyuliantini dan Suarjaya, 2015). Salah satu aset finansial yang diperdagangkan di pasar modal adalah saham. Saham merepresentasikan kepemilikan investor pada suatu perusahaan dan merupakan bentuk investasi yang paling banyak diminati oleh investor karena memberikan return yang diharapkan (Jones, 2004:38).

Investasi saham di pasar modal selain memberikan keuntungan juga mengandung berbagai kemungkinan risiko yang akan terjadi. Terlebih dahulu investor perlu mengenal saham perusahaan apa yang akan dibeli serta mengetahui tingkat return dan risiko yang dimiliki saham perusahaan tersebut (Afriana dkk. 2017). Dalam berinvestasi investor harus bersedia menanggung risiko yang besar dengan ditunjang oleh kesempatan untuk memperoleh return yang besar pula, semakin besar hasil yang diinginkan semakin besar risiko yang akan ditanggung investor dan sebaliknya semakin kecil risiko yang diambil semakin kecil pula hasil yang akan diperoleh investor. Proses pengambilan keputusan harus dikembangkan untuk mengidentifikasi alokasi yang tepat dari setiap investasi yang dilakukan oleh investor (Khaoula dan Slaheddine, 2014).

Strategi yang dapat dilakukan oleh investor dalam berinvestasi saham yaitu diversifikasi. Diversifikasi merupakan strategi yang dilakukan investor untuk menurunkan tingkat risiko dengan cara menanamkan dananya pada instrumen investasi yang beragam atau melakukan pembentukan portofolio. Markowitz (1950) dalam (Zubir, 2011:2) menyatakan investor dapat memaksimumkan expected return melalui diversifikasi instrumen investasi dalam portofolio karena saham - saham dalam portofolio saling berkorelasi. Markowitz juga menjelaskan bahwa investor perlu menganalisis serta memilih instrumen investasi berdasarkan expected return dan variance return dari suatu instrumen investasi tersebut.

Diversifikasi dapat dilakukan menggunakan dua cara yaitu diversifikasi random dan diversifikasi Markowitz. Diversifikasi random terjadi ketika investor secara acak menginvestasikan dananya pada berbagai jenis saham dalam suatu portofolio tanpa memperhatikan karakteristik dan return dari sekuritas itu sendiri (Hartono, 2017:358). Diversifikasi Markowitz terjadi saat investor berinvestasi dengan cara memecah dananya pada berbagai saham yang berbeda - beda dengan 
mempertimbangkan tingkat kovarian dan koefisien korelasi negatif antar saham sehingga dapat meminimumkan tingkat risiko portofolio (Tandelilin, 2010:116).

Portofolio merupakan investasi dari berbagai saham untuk membuat kombinasi yang efisien dari investasi saham tersebut sehingga investor dapat memperoleh return yang diinginkan dengan risiko yang minimum. Yunita (2018) menyatakan permasalahan terbesar dalam menentukan pemilihan portofolio saham adalah saat memilih saham - saham yang akan dijadikan kandidat portofolio. Teori portofolio menjelaskan bahwa investor dapat menginvestasikan berbagai jenis saham di beberapa tempat dengan komposisi yang berbeda untuk menghindari kerugian jika tidak melakukan diversifikasi portofolio tersebut (Maf'ula dkk. 2018). Teori portofolio juga menjelaskan bahwa risiko saham individu dalam suatu portofolio lebih besar dibandingkan risiko portofolio optimal karena variance return saham sebagai ukuran risiko investasi bersifat saling meredam. Teori portofolio memaparkan bagaimana seorang investor dapat melakukan pemilihan portofolio dari beberapa saham untuk memaksimumkan return pada tingkat risiko tertentu yang dapat ditanggung oleh investor (Tandelilin, 2010:156).

Dalam memperoleh return maksimum dengan tingkat risiko yang minimum, investor perlu melakukan optimalisasi portofolio (London et al. 2018). Model yang sering digunakan untuk menyelesaikan masalah optimalisasi portofolio adalah model mean-variance. Model pemilihan portofolio mean-variance dari Markowitz merupakan salah satu model terbaik dalam menentukan portofolio optimal. Dalam bentuk dasarnya, model ini perlu menentukan komposisi portofolio aset yang meminimalkan risiko sehingga mencapai tingkat return yang diharapkan oleh investor. Dalam menentukan portofolio optimal biasanya dilakukan dengan membentuk portofolio yang efisien. Suatu portofolio dapat dikatakan sebagai portofolio yang efisien apabila portofolio yang dibentuk tersebut dapat memberikan expected return terbesar dengan tingkat risiko tertentu. Portofolio yang efisien belum dapat dikatakan sebagai portofolio optimal karena saham - saham yang termasuk ke dalam portofolio efisien hanya disebabkan oleh nilai expected return dari saham tersebut yang tinggi atau saham yang terpilih tersebut memiliki tingkat risiko yang rendah. Pada saat portofolio dibentuk maka investor akan memilih salah satu portofolio optimal dari beberapa portofolio yang terdapat pada portofolio efisien. Dalam pemilihan portofolio optimal investor akan menentukan saham saham yang dipilih sesuai dengan preferensinya (Latulanit dkk. 2018).

Portofolio optimal dapat ditentukan dengan menggunakan tiga model yaitu model Indeks Tunggal, Capital Asset Pricing Model (CAPM), dan Markowitz (Afriana dkk. 2017). Penelitian ini menggunakan model Markowitz sebagai pembentukan portofolio optimal karena model tersebut dapat menunjukkan bagaimana tingkat risiko dari portofolio dapat dikurangi dan bagaimana meningkatkan tingkat return portofolio dalam jangka panjang. Model Markowitz juga mampu mengatasi kelemahan dari diversifikasi yang dilakukan secara acak pada berbagai jenis saham dengan memanfaatkan semua informasi yang tersedia sebagai dasar pembentukan portofolio yang optimal (Tandelilin, 2010:160). Salah satu kelebihan model Markowitz adalah portofolio lebih mudah terbentuk sehingga dapat disesuaikan dengan karakteristik investasi dan tujuan yang diinginkan investor (Natalia dkk. 2014). Dalam penelitian yang dilakukan Paudel dan Koirala 
(2006) menemukan bahwa menggunakan model Markowitz di pasar modal Nepal dapat memberikan pilihan bagi investor dalam membuat keputusan pembentukan portofolio optimal.

Penelitian mengenai pembentukan portofolio optimal menggunakan model Markowitz telah dilakukan oleh berbagai peneliti. Alaoui et al. (2015) melakukan penelitian menggunakan model Markowitz untuk membentuk portofolio optimal pada delapan saham paling aktif di pasar modal Maroko. Model Markowitz yang digunakan dapat mengurangi varians dari portofolio dan juga mampu meningkatkan tingkat return untuk jangka panjang. Metode ini mampu mengurangi varians portofolio dengan rata-rata keseluruhan 26,48 persen.

Penelitian lainnya yang dilakukan oleh Rodrigues dan Suresha (2018) dalam membentuk portofolio optimal dengan menggunakan model Markowitz pada 25 perusahaan yang terdaftar di National Stock Exchange (NSE) India pada periode April 2016 hingga Maret 2017. Penelitiaan ini menggunakan sampel yaitu perusahaan - perusahaan pada sektor IT, perbankan, otomotif, farmasi, serta minyak dan gas. Hasil dari setiap sektor yang dipilih, 7 perusahaan yang berkinerja baik dipilih dalam portofolio yang menghasilkan return maksimum dengan tingkat volatilitas yang lebih rendah.

Penelitian oleh Ivanova dan Dospatliev (2017) mengenai model Markowitz di pasar saham Bulgaria dengan menggunakan 50 saham yang diperdagangkan selama periode Januari 2013 hingga Desember 2016 menghasilkan efisiensi portofolio yang dibentuk oleh model Markowitz mampu berkinerja lebih baik. Penelitian ini juga menunjukkan berinvestasi dalam portofolio yang efisien, investor dapat memperoleh return investasi maksimum dengan tingkat risiko yang minimum. Dengan demikian, investor yang menerapkan model Markowitz dapat meningkatkan kinerja investasi mereka. Penelitian oleh Rifaldy dan Panji (2016) mengenai portofolio optimal menggunakan model Markowitz pada saham indeks Bisnis27 di Bursa Efek Indonesia menemukan sebanyak 5 saham dari 27 saham indeks Bisnis27 periode Mei 2015 hingga Oktober 2015 yang layak masuk ke dalam portofolio optimal dengan pendekatan model Markowitz. Kelima saham tersebut diantaranya AKR Corporindo (AKRA), Indofood CBP Sukses Makmur (ICBP), Lippo Karawaci (LPKR), Surya Citra Media (SCMA), dan Media Nusantara Citra (MNCN).

Penelitian oleh Septyanto dan Kertopati (2014) mengemukakan bahwa dalam menganalis pembentukan portofolio dengan menggunakan model Markowitz dan Indeks Tunggal pada saham indeks LQ45 di Bursa Efek Indonesia tahun 2009 2013, perhitungan menggunakan model Markowitz menghasilkan portofolio dan proporsi yang terbentuk dari saham BBCA (12\%), BBNI (17\%), BMRI (14\%), INDF (19\%), ITMG (12\%), SMGR (13\%), dan UNTR (13\%) memiliki return sebesar 3,008\% dan expected return sebesar 0,43\%, dan risikonya sebesar 0,467\%, sedangkan perhitungan menggunakan model Indeks Tunggal menghasilkan portofolio dan proporsi yang terbentuk dari saham AALI (10\%), BBCA (16\%), BBNI (8\%), BDMN (1\%), BMRI (10\%), INDF (18\%), ITMG (5\%), LSIP (1\%), PGAS (4\%), SMGR (17\%), dan UNTR (10\%), menghasilkan return sebesar $2,753 \%$, expected return sebesar $0,596 \%$, dan risikonya sebesar $0,0264 \%$. Penelitian lainnya oleh Ramadhan dkk. (2014) mengenai portofolio optimal dengan 
berbagai model yang dikembangkan dari model portofolio Markowitz. Model yang dipakai dalam portofolio optimal antara lain, Mean Variance $(M V)$, Downside Deviation (DD), dan Mean Absolute Deviation (MAD) pada Indeks Bisnis27 di Bursa Efek Indonesia periode 2011 - 2013 dengan menggunakan 10 sampel perusahaan. $M A D$ adalah model portofolio optimal yang mampu memberikan return yang maksimum, kinerja yang optimal, dan memberikan risiko yang paling kecil sehingga tepat untuk investor dengan preferensi risk seeker.

Penelitian oleh Mahayani dan Suarjaya (2019) mengenai portofolio optimal menggunakan model Markowitz pada perusahaan Infrastruktur periode Januari Desember 2017 menghasilkan bahwa dari 31 saham yang menjadi kandidat portofolio optimal terdapat 23 saham yang dinyatakan sebagai portofolio optimal dengan proporsi dana akhir masing - masing saham yaitu, AKSI $(1,830 \%)$, BALI (12,289\%), BUKK (0,005\%), CMNP (0,009\%), CMPP (0,053\%), EXCL $(16,490 \%)$, IBST $(6,585 \%)$, KOPI $(0,002 \%)$, META $(0,003 \%)$, NELY $(7,124 \%)$, OASA $(3,621 \%)$, POWR (0,219\%), RAJA (11,685\%), RIGS (0,386\%), SAFE $(1,778 \%)$, SDMU $(7,660 \%)$, SHIP $(8,842 \%)$, SMDR $(18,515 \%)$, TBIG $(1,384 \%)$, TLKM $(0,075 \%)$, TOWR $(0,006 \%)$, TRAM $(1,429 \%)$, dan WINS $(0,009 \%)$ serta memberikan expected return portofolio sebesar 5,085\% dengan risiko portofolio sebesar 0,004\%.

Penelitian yang dilakukan Setyawati dan Sudiartha (2019) menggunakan model Markowitz pada indeks IDX30 periode Januari 2017 - Januari 2018 menghasilkan 7 saham yang menjadi anggota portofolio optimal dengan proporsi masing - masing saham yaitu, ADRO (0,55\%), ASII (0,15\%), GGRM $(17,61 \%)$, $\operatorname{ICBP}(9,46 \%)$, MEDC $(5,275)$, UNVR $(41,11 \%)$, dan UNTR $(25,86 \%)$, dengan memberikan expected return portofolio sebesar 3,2\% dengan tingkat risiko portofolio sebesar 3,3\%. Pembentukan portofolio optimal ini dibantu dengan program Solver pada Microsoft Excel. Penelitian ini menyatakan dengan bantuan program Solver, maka expected return portofolio yang diperoleh investor meningkat sebesar $0,3 \%$, sedangkan risiko portofolio yang ditanggung oleh investor menurun sebesar $1,3 \%$.

Penelitian yang dilakukan oleh peneliti dimaksudkan untuk mengetahui tingkat return dan risiko portofolio melalui pembentukan portofolio optimal. Berbeda dengan penelitian sebelumnya yang mayoritas menggunakan indeks LQ45, Bisnis27, dan IDX30, maka penelitian kali ini menggunakan saham - saham pada indeks IDX80. Indeks IDX80 merupakan indeks baru yang dikeluarkan oleh Bursa Efek Indonesia pada awal tahun 2019. Indeks IDX80 adalah indeks yang digunakan untuk mengukur pergerakan rata-rata dari 80 saham unggulan yang tergabung dalam indeks tersebut.

Hasil penelitian yang dilakukan Lee et al. (2016) menunjukkan bahwa saham - saham yang terdaftar di Bursa Malaysia tidak cocok bagi investor dalam mendiversifikasikan portofolionya apabila menggunakan model Markowitz. Bhullar dan Gupta (2016) meneliti 30 saham yang terdaftar di Bombay Stock Exchange India selama periode 2006 - 2014 menggunakan model Markowitz. Hasil penelitian menunjukkan bahwa model Markowitz tidak cocok untuk diterapkan pada 30 saham yang digunakan sebagai sampel penelitian karena hasil dari return realisasi lebih rendah dari expected return. 
Penelitian yang dilakukan oleh Kulali (2016) pada sepuluh perusahaan yang dipilih secara acak dari tiga industri yang berbeda di Bursa Efek Istanbul dengan menggunakan model mean - variance menunjukkan bahwa portofolio optimal yang dibangun oleh delapan saham dengan bobot berbeda menghasilkan return lebih besar dibandingkan portofolio dengan saham yang bobotnya sama dari sepuluh saham. Radovic et al. (2018) melakukan penelitian terhadap 21 saham yang terdaftar di pasar modal Serbia. Hasil penelitian menunjukkan bahwa portofolio efisien dapat memberikan return maksimal dengan risiko yang dapat diminimumkan. Model Markowitz memungkinkan investor untuk memilih portofolio yang efisien, tetapi hanya untuk saham yang likuid sesuai dengan risiko yang diterima investor.

Penelitian lainnya yang dilakukan oleh Shao et al. (2016) pada 50 saham yang terdaftar di Bursa Shanghai periode 1 Januari 2011 hingga 31 Oktober 2014 dengan menggunakan model Markowitz modifikasi berdasarkan LDIW-PSO. Hasil penelitian menyatakan LDIW-PSO sangat cocok untuk mengoptimalkan model portofolio investasi. Penelitian oleh Suresh dan Narshitha (2017) menggunakan model Indeks Sharpe dan model Markowitz pada saham yang terdaftar di Bombay Stock Exchange. Penelitian membuktikan bahwa tidak ada perbedaan dalam nilai return dan risiko sesuai model Markowitz dan model Indeks Sharpe. Return dan risikonya sama, namun dalam hal ini perhitungan risiko portofolio model Indeks Sharpe lebih mudah daripada model Markowitz karena hasil perhitungan model Indeks Sharpe lebih cepat dari model Markowitz.

Mitra (2014) melakukan penelitian pada saham Sensex30 dan Nifty50 yang diperdagangkan di Bursa Efek Bombay dan Bursa Efek Nasional menggunakan model Indeks Sharpe dan model Markowitz. Hasil penelitian menunjukkan bahwa investor akan mendapatkan return yang lebih besar dengan tingkat risiko minimum jika investor berinvestasi pada portofolio yang tingkat risiko dan returnnya mendekati Capital Market Line (CML). Penelitian lainnya oleh Solanki (2014) mengenai optimalitas portofolio dengan model Markowitz pada indeks SENSEX 30 di Bursa Efek Bombay periode 2008 - 2012 menunjukkan dengan melakukan diversifikasi portofolio pada 14 saham yang menjadi sampel penelitian akan memberikan return yang maksimal bagi investor.

Penelitian oleh Iqbal et al. (2019) pada 100 perusahaan yang terdaftar di Bursa Efek Pakistan mengenai seleksi portofolio optimal menggunakan model Markowitz mean-variance. Hasil penelitian menunjukkan saham dari perusahaan yang terdaftar di Bursa Efek Pakistan, model mean-variance dapat digunakan sebagai alat preferensi untuk memperkirakan risiko dan expected return dari saham yang diteliti. Penelitian lainnya dilakukan oleh Natalia dkk. (2014) mengenai pembentukan portofolio optimal menggunakan model Markowitz. Terdapat sembilan saham yang tergolong dalam portofolio optimal. Saham-saham tersebut adalah: (AISA) dengan proporsi sebesar 2,86\%, (DLTA) dengan proporsi sebesar $16,20 \%$, (ICBP) dengan proporsi sebesar $8,34 \%$, (INDF) dengan proporsi sebesar $14,21 \%$, (MLBI) dengan proporsi sebesar 6,86\%, (MYOR) dengan proporsi sebesar $8,10 \%$, (ROTI) dengan proporsi sebesar 5,72\%, (SKLT) dengan proporsi sebesar $31,33 \%$, dan (ULTJ) dengan proporsi sebesar 6,39\%. 
Penelitian oleh Azizah dkk. (2017) pada 21 saham perusahaan yang terdaftar di Jakarta Islamic Index (JII) dengan menggunakan model Markowitz dan model Indeks Tunggal menunjukkan bahwa terdapat 8 saham perusahaan yang membentuk portofolio optimal berdasarkan model Markowitz dengan komposisi dana (AALI) sebesar 2,88\%, (ICBP) sebesar 3,23\%, (INDF) sebesar 30,93\%, (LSIP) sebesar 0,46\%, (PGAS) sebesar 6,04\%, (SMGR) sebesar 11,88\%, (UNTR) sebesar 26,48\%, (UNVR) sebesar 18,10\%. Berdasarkan model Indeks Tunggal terdapat 9 saham yang membentuk portofolio optimal dengan komposisi dana (UNTR) sebesar 17,15\%, (UNVR) sebesar 2,77\%, (AALI) sebesar 10,85\%, (KLBF) sebesar 39,11\%, (ICBP) sebesar 0,88\%, (INDF) sebesar 15,95\%, (BSDE) sebesar $12,79 \%$, (LSIP) sebesar 0,14\%, dan (AKRA) sebesar 0,36\%.

Pracanda dan Abundanti (2017) melakukan penelitian model Markowitz pada 30 saham indeks IDX30 di Bursa Efek Indonesia periode Agustus 2015 - Juli 2016. Hasil penelitian menunjukkan bahwa terdapat 6 saham yang terpilih menjadi anggota portofolio optimal dengan proporsi masing-masing yaitu sebesar 9.57 persen saham ADHI, 28.92 persen saham BBCA, 6.20 persen saham LPKR, 18.99 persen saham SCMA, 25.38 persen saham TLKM, dan 10.94 persen saham UNVR. Pratiwi dkk. (2014) melakukan penelitian pada saham yang terdaftar dalam Jakarta Islamic Indeks di Bursa Efek Indonesia periode Mei 2011 sampai dengan November 2013 menunjukkan analisis model Markowitz dari 16 perusahaan menghasilkan 9 perusahaan sebagai portofolio optimal dengan proporsi dana terbesar dimiliki oleh PT Astra Agro Lestari Tbk (AALI) yang mempunyai risiko tertentu dengan tingkat return tertentu, sedangkan hasil analisis dari Model Indeks Tunggal menghasilkan 8 perusahaan sebagai portofolio optimal dengan proporsi dana terbesar dimiliki oleh PT Unilever Indonesia Tbk (UNVR) yang memiliki risiko individual terendah dan pengaruh pasar tidak berdampak pada kinerja saham yang terpilih ke dalam portofolio optimal.

\section{METODE PENELITIAN}

Penelitian ini dilakukan di Bursa Efek Indonesia (BEI) pada saham-saham yang terdaftar dalam indeks IDX80 periode Februari-September 2019. Obyek penelitian ini adalah saham-saham dalam indeks IDX80 yang terbentuk sebagai portofolio optimal di Bursa Efek Indonesia periode Februari-September 2019.

Harga saham yang digunakan dalam penelitian ini adalah harga penutupan saham (closing price) setiap bulan pada masing - masing perusahaan yang termasuk dalam indeks IDX80 periode Februari - September 2019.

Return saham merupakan hasil yang didapatkan dalam melakukan investasi berupa capital gain/loss. Return saham dalam penelitian ini menggunakan selisih dari harga saham pada saat ini dengan yang sebelumnya pada perusahaan yang termasuk dalam indeks IDX80 periode Februari - September 2019. Persamaan return saham adalah sebagai berikut (Hartono, 2017:284):

$R_{i t}=\frac{P_{t-P_{t-1}}}{P_{t-1}}$

Keterangan:

$R_{i t} \quad=$ Return saham i pada periode $\mathrm{t}$ 
$P_{t} \quad=$ Harga saham i pada periode $\mathrm{t}$

$P_{t-1}=$ Harga saham i pada periode $\mathrm{t}-1$

Expected return saham merupakan hasil yang diharapkan dari investasi yang dilakukan investor di masa datang. Expected return saham pada penelitian ini adalah rata - rata dari return saham yang terdaftar pada indeks IDX80 periode Februari - September 2019. Persamaan expected return adalah sebagai berikut (Hartono, 2017:300):

$E\left(R_{i}\right)=\frac{\sum_{i=1}^{n} R_{i t}}{n}$

Keterangan:

$\begin{array}{ll}E\left(R_{i}\right) & =\text { Expected return pada saham } \mathrm{i} \\ R_{i t} & =\text { Return } \text { pada saham } \mathrm{i} \text { pada periode } \mathrm{t} \\ n & =\text { Jumlah periode pengamatan }\end{array}$

Risiko saham adalah risiko yang terjadi ketika terdapat perbedaan antar return aktual dan return harapan. Risiko saham ada penelitian ini dihitung menggunakan standar deviasi pada perusahaan yang termasuk dalam indeks IDX80 periode Februari - September 2019. Persamaan untuk standar deviasi adalah sebagai berikut (Hartono, 2017:307):

$\mathrm{SD}=\sqrt{\frac{\sum_{i=1}^{n}|R i-E(R i)|^{2}}{n}}$

Keterangan:

SD $\quad=$ Standar deviasi

Ri $\quad=$ Nilai saham ke i

$E(R i) \quad=$ Nilai Expected return saham ke i

$n \quad=$ Jumlah observasi data historis untuk sampel besar dengan $\mathrm{n}$ (paling sedikit 30 observasi) dan untuk sampel kecil digunakan (n-1)

Koefisien korelasi menunjukkan seberapa besar hubungan antar satu saham terkait dengan saham lainnya pada perusahaan yang termasuk dalam indeks IDX80 periode Februari - September 2019. Nilai koefisien korelasi dapat dihitung dengan persamaan sebagai berikut (Hartono, 2017:342):

$\mathrm{R}_{\mathrm{A}, \mathrm{B}}=\frac{\sum_{i=1}^{n}\left(R_{A, i}-R_{B, i}\right)-n \cdot E\left(R_{A}\right) \cdot E\left(R_{B}\right)}{\sqrt{\left[\sum_{i=1}^{n} R_{A, i}{ }^{2}-n \cdot E\left(R_{A, i}\right)^{2}\right]\left[\sum_{i=1}^{n} R_{B, i}{ }^{2}-n \cdot E\left(R_{B, i}\right)^{2}\right]}}$

Keterangan:

$R_{A, B} \quad=$ Koefisien korelasi return saham A dan $\mathrm{B}$

$R_{A, i} \quad=$ Return saham A pada periode $\mathrm{t}$

$R_{B, i} \quad=$ Return saham $\mathrm{B}$ pada periode $\mathrm{t}$

$E\left(R_{A}\right)=$ Expected return $\mathrm{A}$

$E\left(R_{B}\right)=$ Expected return $\mathrm{B}$

$n \quad=$ Banyaknya periode pengamatan

Kovarian menjelaskan seberapa besar kecenderungan suatu saham dengan saham lainnya bergerak secara bersamaan. Kovarian antar saham perusahaan yang 
termasuk salam indeks IDX80 periode Februari - September 2019 dapat dihitung dengan persamaan sebagai berikut (Hartono, 2017:340):

$\sigma_{R A, R B}=\sum_{i=1}^{n} \frac{\left[\left(R_{A i}-E\left(R_{A}\right) \cdot\left(R_{B i}-E\left(R_{B}\right)\right]\right.\right.}{n}$

Keterangan:

$\begin{array}{ll}\sigma_{R A, R B} & =\text { Kovarian return antar saham A dan saham B } \\ R_{A i} & =\text { Return masa depan saham A kondisi ke-i } \\ R_{B i} & =\text { Return masa depan saham B kondisi ke-i } \\ E\left(R_{A}\right) & =\text { Expected return saham A } \\ E\left(R_{B}\right) & =\text { Expected return saham B } \\ n & =\text { Jumlah observasi data historis untuk sampel besar (minimal } 30 \\ \text { observasi) dan } & \text { untuk sampel kecil digunakan (n-1) }\end{array}$

Expected return portofolio merupakan rata - rata tertimbang dari return return ekspektasian masing - masing saham dalam portofolio yang dihitung dengan mengalikan expected return masing - masing saham dengan bobot atau proporsi saham dalam portofolio. Expected return portofolio perusahaan yang termasuk dalam indeks IDX80 periode Februari - September 2019 dapat dihitung dengan persamaan berikut (Hartono, 2017:332):

$E(R p)=\sum_{i=1}^{n}\left(w_{i} . E\left(R_{i}\right)\right)$

Keterangan:

$E(R p)=$ Return ekspektasian dari portofolio

$E(R i)=$ Return yang diharapkan dari saham $\mathrm{i}$

$w_{i} \quad=$ Porsi dari saham i terhadap seluruh saham portofolio

$n \quad=$ Jumlah saham yang ada dalam portofolio

Risiko portofolio merupakan penjumlahan dari kovarian dengan proporsi masing - masing saham yang ada di dalamnya, maka risiko ini dapat dituliskan dalam bentuk perkalian matrik antar matrik kovarian dengan matrik proporsi masing - masing perusahaan yang termasuk dalam indeks IDX80 periode Februari - September 2019. Risiko portofolio dapat dihitung dengan persamaan sebagai berikut (Hartono, 2017:352):

$$
\sigma_{p}=\sqrt{\sum_{i=1}^{n} \sum_{j=1}^{n} w_{i} \cdot w_{j} \cdot \sigma_{i j}}
$$

Keterangan:

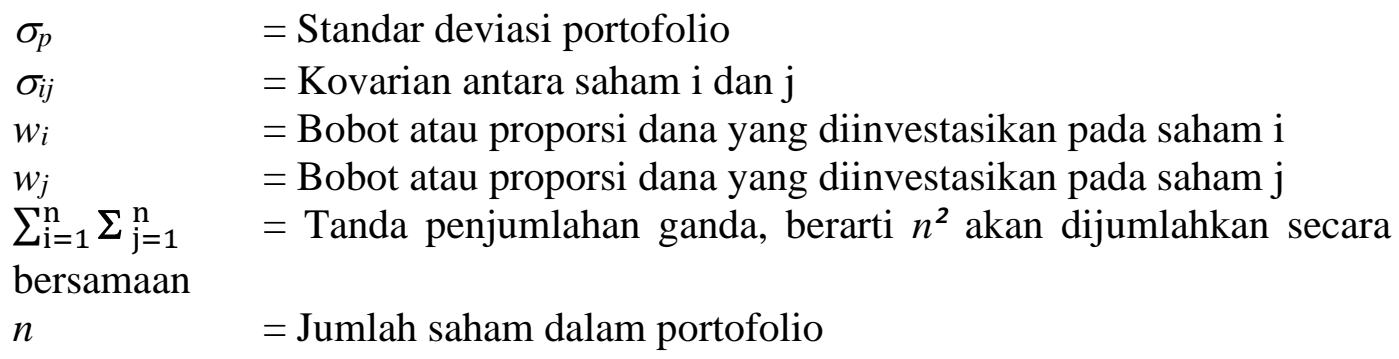

Proporsi dana optimal dapat dihitung dengan bantuan program Solver Linear Programming pada Microsoft Excel. Tujuan program Solver adalah untuk 
menghitung berapa pembagian proporsi dana optimal masing - masing saham yang menjadi kandidat portofolio optimal. Setelah mendapatkan proporsi dana optimal, selanjutnya untuk menghitung expected return dan risiko portofolio optimal kembali menggunakan persamaan sesuai dengan perhitungan expected return portofolio (no. 6) dan risiko portofolio (no.7).

Populasi yang digunakan dalam penelitian ini adalah seluruh perusahaan yang terdaftar dalam indeks IDX80 pada periode Februari - September 2019. Sampel yang digunakan dari penelitian ini yaitu menggunakan teknik purposive sampling dengan metode penentuan sampel berdasarkan pertimbangan atau kriteria yang ditentukan.

Kriteria yang tergolong sampel penelitian yaitu saham - saham yang terdaftar selama 2 periode pembaruan indeks IDX80. Berdasarkan data yang diperoleh selama 2 periode pembaruan indeks IDX80, terdapat 6 saham yang keluar dari indeks IDX80 yaitu PT Gajah Tunggal Tbk (GJTL), PT Petrosea Tbk (PTRO), PT Tunas Baru Lampung Tbk (TBLA), PT Bekasi Fajar Industrial Estate Tbk (BEST), PT BPD Jawa Timur Tbk (BJTM), dan PT Link Net Tbk (LINK) yang digantikan dengan 6 saham penghuni baru indeks IDX80 yaitu PT Global Mediacom Tbk (BMTR), PT BPTN Syariah Tbk (BTPS), PT Lippo Karawaci Tbk (LPKR), PT Panin Financial Tbk (PNLF), PT Sawit Sumbermas Sarana Tbk (SSMS), dan PT Totalindo Eka Persada Tbk (TOPS), sehingga sampel penelitian berdasarkan kriteria selama periode Februari - September 2019 adalah populasi penelitian: 80 saham, saham yang tidak terdaftar selama 2 periode pembaruan: 6 saham, sampel penelitian (populasi - saham yang tidak terdaftar): 74 saham.

Penelitian ini menggunakan data harga penutupan pada saham indeks IDX80 Periode Januari 2019. Setelah data terkumpul, selanjutnya dilakukan analisis dengan menggunakan model Markowitz. Perhitungan model Markowitz dapat dipermudah dengan menggunakan program Solver Linear Programming yang terdapat pada Microsoft Excel.

\section{HASIL DAN PEMBAHASAN}

Hasil penelitian ini meliputi proses dari penentuan pembentukan portofolio optimal pada saham indeks IDX80 periode Februari-September 2019 dengan menggunakan model Markowitz. Berikut proses penentuan pembentukan portofolio optimal dengan tahapan-tahapannya.

Tahap pertama adalah mencari harga penutupan saham (closing price) per bulan pada masing - masing saham indeks IDX80 periode Januari - September 2019 yang termasuk sampel penelitian di www.investing.com.

Tahap kedua adalah menghitung return dan expected return masing - masing saham yang termasuk dalam sampel penelitian. Expected return menjelaskan keuntungan ekspektasi yang mungkin diperoleh dari masing - masing saham yang dapat bernilai positif maupun negatif. Return didapat dari selisih antara harga saham saat ini dengan harga saham sebelumnya dibagi dengan harga saham sebelumnya. Expected return didapat berdasarkan nilai rata - rata dari total return masing - masing saham. Adapun hasil dari perhitungan return dan expected return 
masing - masing saham yang termasuk dalam sampel penelitian dapat dilihat pada Tabel 1, yaitu:

Tabel 1.

Return dan Expected Return Masing - Masing Saham Indeks IDX80 Periode Februari - September 2019

\begin{tabular}{|c|c|c|c|c|c|c|c|}
\hline No & Kode Saham & $\Sigma$ Rit & $\mathbf{E}(\mathbf{R i})$ & No & Kode Saham & $\Sigma$ Rit & $\mathbf{E}(\mathbf{R i})$ \\
\hline 1 & AALI & $-24,637 \%$ & $-3,080 \%$ & 38 & JPFA & $-54,844 \%$ & $-6,856 \%$ \\
\hline 2 & ACES & $4,826 \%$ & $0,603 \%$ & 39 & JSMR & $16,449 \%$ & $2,056 \%$ \\
\hline 3 & ADHI & $-14,964 \%$ & $-1,870 \%$ & 40 & KLBF & $6,371 \%$ & $0,796 \%$ \\
\hline 4 & ADRO & $-5,173 \%$ & $-0,647 \%$ & 41 & LPPF & $-60,421 \%$ & $-7,553 \%$ \\
\hline 5 & AKRA & $-29,217 \%$ & $-3,652 \%$ & 42 & LSIP & $-9,130 \%$ & $-1,141 \%$ \\
\hline 6 & ANTM & $6,691 \%$ & $0,836 \%$ & 43 & MAIN & $-59,675 \%$ & $-7,459 \%$ \\
\hline 7 & ASII & $-22,943 \%$ & $-2,868 \%$ & 44 & MAPI & $4,077 \%$ & $0,510 \%$ \\
\hline 8 & ASRI & $-18,984 \%$ & $-2,373 \%$ & 45 & MEDC & $-35,499 \%$ & $-4,437 \%$ \\
\hline 9 & BBCA & $7,640 \%$ & $0,955 \%$ & 46 & MIKA & $66,950 \%$ & $8,369 \%$ \\
\hline 10 & BBNI & $-18,631 \%$ & $-2,329 \%$ & 47 & MNCN & $50,693 \%$ & $6,337 \%$ \\
\hline 11 & BBRI & $7,796 \%$ & $0,974 \%$ & 48 & MYOR & $-13,844 \%$ & $-1,731 \%$ \\
\hline 12 & BBTN & $-30,689 \%$ & $-3,836 \%$ & 49 & PGAS & $-18,514 \%$ & $-2,314 \%$ \\
\hline 13 & BDMN & $-46,818 \%$ & $-5,852 \%$ & 50 & PNBN & $-2,339 \%$ & $-0,292 \%$ \\
\hline 14 & BJBR & $-35,624 \%$ & $-4,453 \%$ & 51 & PPRO & $-42,948 \%$ & $-5,368 \%$ \\
\hline 15 & BKSL & $-1,487 \%$ & $-0,186 \%$ & 52 & PTBA & $-59,627 \%$ & $-7,453 \%$ \\
\hline 16 & BMRI & $-5,704 \%$ & $-0,713 \%$ & 53 & РТPP & $-25,385 \%$ & $-3,173 \%$ \\
\hline 17 & BNGA & $-6,478 \%$ & $-0,810 \%$ & 54 & PWON & $4,112 \%$ & $0,514 \%$ \\
\hline 18 & BNLI & $14,273 \%$ & $1,784 \%$ & 55 & RALS & $-23,807 \%$ & $-2,976 \%$ \\
\hline 19 & BRPT & $72,912 \%$ & $9,114 \%$ & 56 & SCMA & $-44,040 \%$ & $-5,505 \%$ \\
\hline 20 & BSDE & $6,027 \%$ & $0,753 \%$ & 57 & SMGR & $-6,061 \%$ & $-0,758 \%$ \\
\hline 21 & CPIN & $-28,244 \%$ & $-3,531 \%$ & 58 & SMRA & $17,824 \%$ & $2,228 \%$ \\
\hline 22 & CTRA & $13,504 \%$ & $1,688 \%$ & 59 & SMSM & $-2,927 \%$ & $-0,366 \%$ \\
\hline 23 & ELSA & $-11,242 \%$ & $-1,405 \%$ & 60 & SRIL & $-6,244 \%$ & $-0,781 \%$ \\
\hline 24 & ERAA & $3,241 \%$ & $0,405 \%$ & 61 & SSIA & $49,289 \%$ & $6,161 \%$ \\
\hline 25 & ESSA & $-43,008 \%$ & $-5,376 \%$ & 62 & TBIG & $31,944 \%$ & $3,993 \%$ \\
\hline 26 & EXCL & $48,368 \%$ & $6,046 \%$ & 63 & TINS & $-25,180 \%$ & $-3,148 \%$ \\
\hline 27 & GGRM & $-42,542 \%$ & $-5,318 \%$ & 64 & TKIM & $-18,128 \%$ & $-2,266 \%$ \\
\hline 28 & HMSP & $-48,889 \%$ & $-6,111 \%$ & 65 & TLKM & $10,519 \%$ & $1,315 \%$ \\
\hline 29 & HOKI & $17,361 \%$ & $2,170 \%$ & 66 & TOWR & $-24,453 \%$ & $-3,057 \%$ \\
\hline 30 & HRUM & $-23,692 \%$ & $-2,962 \%$ & 67 & TPIA & $43,673 \%$ & $5,459 \%$ \\
\hline 31 & ICBP & $12,554 \%$ & $1,569 \%$ & 68 & UNTR & $-19,257 \%$ & $-2,407 \%$ \\
\hline 32 & INCO & $-5,114 \%$ & $-0,639 \%$ & 69 & UNVR & $-6,042 \%$ & $-0,755 \%$ \\
\hline 33 & INDF & $1,706 \%$ & $0,213 \%$ & 70 & WIKA & $5,936 \%$ & $0,742 \%$ \\
\hline 34 & INDY & $-42,885 \%$ & $-5,361 \%$ & 71 & WOOD & $40,174 \%$ & $5,022 \%$ \\
\hline 35 & INKP & $-59,546 \%$ & $-7,443 \%$ & 72 & WSBP & $-15,209 \%$ & $-1,901 \%$ \\
\hline 36 & INTP & $0,303 \%$ & $0,038 \%$ & 73 & WSKT & $-14,301 \%$ & $-1,788 \%$ \\
\hline 37 & ITMG & $-54,145 \%$ & $-6,768 \%$ & 74 & WTON & $24,968 \%$ & $3,121 \%$ \\
\hline
\end{tabular}

Sumber: Data diolah, 2019

Tabel 1. menunjukkan dari 74 saham perusahaan yang menjadi sampel penelitian, 28 saham memberikan expected return positif dan 46 saham memberikan expected return negatif. Tabel di atas memperlihatkan bahwa saham yang memberikan expected return tertinggi adalah saham BRPT dengan rata - rata sebesar 9,114 persen, sedangkan saham yang memberikan expected return terendah adalah saham LPPF dengan rata- rata sebesar -7,553 persen. Saham yang memberikan expected return positif akan lolos menjadi kandidat dari penentuan portofolio optimal dan saham yang memberikan expected return negatif tidak lolos 
menjadi kandidat penentuan portofolio optimal dan akan dikeluarkan. Berikut merupakan saham yang memiliki expected return positif dan menjadi kandidat penentuan portofolio optimal dapat dilihat pada Tabel 2. yaitu:

Tabel 2.

Expected Return Saham Indeks IDX80 yang Bernilai Positif Periode Februari - September 2019

\begin{tabular}{clrlllrl}
\hline No & Kode Saham & \multicolumn{1}{c}{$\boldsymbol{\Sigma}$ Rit } & E(Ri) & No & Kode Saham & \multicolumn{1}{c}{$\boldsymbol{\Sigma}$ Rit } & E(Ri) \\
\hline 1 & ACES & $4,826 \%$ & $0,603 \%$ & 15 & JSMR & $16,449 \%$ & $2,056 \%$ \\
2 & ANTM & $6,691 \%$ & $0,836 \%$ & 16 & KLBF & $6,371 \%$ & $0,796 \%$ \\
3 & BBCA & $7,640 \%$ & $0,955 \%$ & 17 & MAPI & $4,077 \%$ & $0,510 \%$ \\
4 & BBRI & $7,796 \%$ & $0,974 \%$ & 18 & MIKA & $66,950 \%$ & $8,369 \%$ \\
5 & BNLI & $14,273 \%$ & $1,784 \%$ & 19 & MNCN & $50,693 \%$ & $6,337 \%$ \\
6 & BRPT & $72,912 \%$ & $9,114 \%$ & 20 & PWON & $4,112 \%$ & $0,514 \%$ \\
7 & BSDE & $6,027 \%$ & $0,753 \%$ & 21 & SMRA & $17,824 \%$ & $2,228 \%$ \\
8 & CTRA & $13,504 \%$ & $1,688 \%$ & 22 & SSIA & $49,289 \%$ & $6,161 \%$ \\
9 & ERAA & $3,241 \%$ & $0,405 \%$ & 23 & TBIG & $31,944 \%$ & $3,993 \%$ \\
10 & EXCL & $48,368 \%$ & $6,046 \%$ & 24 & TLKM & $10,519 \%$ & $1,315 \%$ \\
11 & HOKI & $17,361 \%$ & $2,170 \%$ & 25 & TPIA & $43,673 \%$ & $5,459 \%$ \\
12 & ICBP & $12,554 \%$ & $1,569 \%$ & 26 & WIKA & $5,936 \%$ & $0,742 \%$ \\
13 & INDF & $1,706 \%$ & $0,213 \%$ & 27 & WOOD & $40,174 \%$ & $5,022 \%$ \\
14 & INTP & $0,303 \%$ & $0,038 \%$ & 28 & WTON & $24,968 \%$ & $3,121 \%$ \\
\hline \multicolumn{7}{l}{ Sumber }
\end{tabular}

Sumber: Data diolah, 2019

Tahap ketiga adalah menghitung standar deviasi masing - masing saham sampel penelitian yang memiliki expected return positif. Standar deviasi digunakan untuk menghitung risiko saham. Berikut merupakan hasil perhitungan standar deviasi masing - masing saham yang memiliki expected return positif, yaitu:

Tabel 3.

Standar Deviasi Masing - Masing Saham Indeks IDX80 yang Memiliki Expected Return Positif

\begin{tabular}{clrrlr}
\hline No & Kode Saham & $\begin{array}{r}\text { Standar } \\
\text { Deviasi }\end{array}$ & No & Kode Saham & $\begin{array}{r}\text { Standar } \\
\text { Deviasi }\end{array}$ \\
\hline 1 & ACES & $4,672 \%$ & 15 & JSMR & $6,855 \%$ \\
2 & ANTM & $12,689 \%$ & 16 & KLBF & $7,233 \%$ \\
3 & BBCA & $2,207 \%$ & 17 & MAPI & $6,648 \%$ \\
4 & BBRI & $5,328 \%$ & 18 & MIKA & $13,844 \%$ \\
5 & BNLI & $11,854 \%$ & 19 & MNCN & $18,858 \%$ \\
6 & BRPT & $13,264 \%$ & 20 & PWON & $7,142 \%$ \\
7 & BSDE & $6,858 \%$ & 21 & SMRA & $13,850 \%$ \\
8 & CTRA & $12,700 \%$ & 22 & SSIA & $15,459 \%$ \\
9 & ERAA & $29,531 \%$ & 23 & TBIG & $17,786 \%$ \\
10 & EXCL & $5,291 \%$ & 24 & TLKM & $3,632 \%$ \\
11 & HOKI & $10,704 \%$ & 25 & TPIA & $17,982 \%$ \\
12 & ICBP & $6,592 \%$ & 26 & WIKA & $11,430 \%$ \\
13 & INDF & $8,233 \%$ & 27 & WOOD & $19,137 \%$ \\
14 & INTP & $9,212 \%$ & 28 & WTON & $16,251 \%$ \\
\hline
\end{tabular}

Sumber: Data diolah, 2019

Tabel 3. menunjukkan saham yang memberikan standar deviasi tertinggi adalah saham ERAA dengan nilai sebesar 29,531 persen, sedangkan saham yang 
memberikan standar deviasi terendah adalah saham BBCA dengan nilai sebesar 2,207 persen.

Tahap keempat adalah menghitung korelasi antar saham yang menjadi kandidat portofolio optimal. Korelasi antar saham diharapkan dapat mengurangi risiko yang terjadi dalam berinvestasi. Saham yang memiliki nilai korelasi dibawah 0 hingga -1 akan membantu mengurangi risiko secara efektif. Perhitungan korelasi antar saham menggunakan bantuan Microsoft Excel.

Tahap kelima adalah menghitung kovarian antar saham yang menjadi kandidat portofolio optimal. Kovarian antar saham menunjukkan kecenderungan dua sekuritas bergerak bersama-sama. Kovarian bernilai positif berarti kecenderungan dua sekuritas bergerak ke arah yang sama. Kovarian bernilai negatif berarti kecenderungan dua sekuritas bergerak ke arah yang berlawanan, sedangkan kovarian bernilai nol berarti pergerakan dua sekuritas bersifat independen atau pergerakan satu sekuritas tidak berhubungan dengan pergerakan sekuritas lainnya. Perhitungan kovarian antar saham menggunakan bantuan Microsoft Excel.

Tahap keenam adalah menghitung expected return dan risiko portofolio menggunakan kovarian antar saham kandidat portofolio optimal dengan proporsi yang sama. Proporsi awal dapat menggunakan asumsi bahwa proporsi seluruh saham dalam portofolio ini adalah sama. Perhitungan proporsi sama menggunakan rumus 100 persen dibagi jumlah saham yang menjadi kandidat portofolio optimal, sehingga masing - masing saham mendapatkan alokasi dana sebesar 100/28 $=3,571$ persen. Berikut merupakan hasil perhitungan expected return dan risiko portofolio menggunakan proporsi sama, yaitu:

Tabel 4.

Expected Return dan Risiko Portofolio dengan Menggunakan Proporsi Sama

\begin{tabular}{clrrlr}
\hline No & Kode Saham & Proporsi & No & Kode Saham & Proporsi \\
\hline 1 & ACES & $3,571 \%$ & 15 & JSMR & $3,571 \%$ \\
2 & ANTM & $3,571 \%$ & 16 & KLBF & $3,571 \%$ \\
3 & BBCA & $3,571 \%$ & 17 & MAPI & $3,571 \%$ \\
4 & BBRI & $3,571 \%$ & 18 & MIKA & $3,571 \%$ \\
5 & BNLI & $3,571 \%$ & 19 & MNCN & $3,571 \%$ \\
6 & BRPT & $3,571 \%$ & 20 & PWON & $3,571 \%$ \\
7 & BSDE & $3,571 \%$ & 21 & SMRA & $3,571 \%$ \\
8 & CTRA & $3,571 \%$ & 22 & SSIA & $3,571 \%$ \\
9 & ERAA & $3,571 \%$ & 23 & TBIG & $3,571 \%$ \\
10 & EXCL & $3,571 \%$ & 24 & TLKM & $3,571 \%$ \\
11 & HOKI & $3,571 \%$ & 25 & TPIA & $3,571 \%$ \\
12 & ICBP & $3,571 \%$ & 26 & WIKA & $3,571 \%$ \\
13 & INDF & $3,571 \%$ & 27 & WOOD & $3,571 \%$ \\
14 & INTP & $3,571 \%$ & 28 & WTON & $3,571 \%$ \\
& & Expected Return & & & $\mathbf{2 , 6 3 5 \%}$ \\
& & Standar Deviasi & & & $\mathbf{3 , 8 7 9 \%}$ \\
\hline
\end{tabular}

Sumber: Data diolah, 2019

Tabel 4. menunjukkan bahwa portofolio yang dibentuk oleh 28 saham kandidat portofolio optimal menggunakan proporsi sama sebesar 3,571 persen menghasilkan expected return sebesar 2,635 persen dan tingkat risiko sebesar 3,879 persen. 
Tahap ketujuh adalah menghitung expected return dan risiko portofolio menggunakan kovarian antar saham kandidat portofolio optimal dengan proporsi optimal. Portofolio optimal dibentuk menggunakan Microsoft Excel dengan aplikasi program Solver. Perhitungan proporsi menggunakan bantuan program Solver memperlihatkan proporsi dana akhir optimal yang layak dialokasikan pada masing - masing saham yang menjadi kandidat portofolio optimal. Contoh dari pengaturan untuk program Solver dapat dilihat pada Gambar 1.

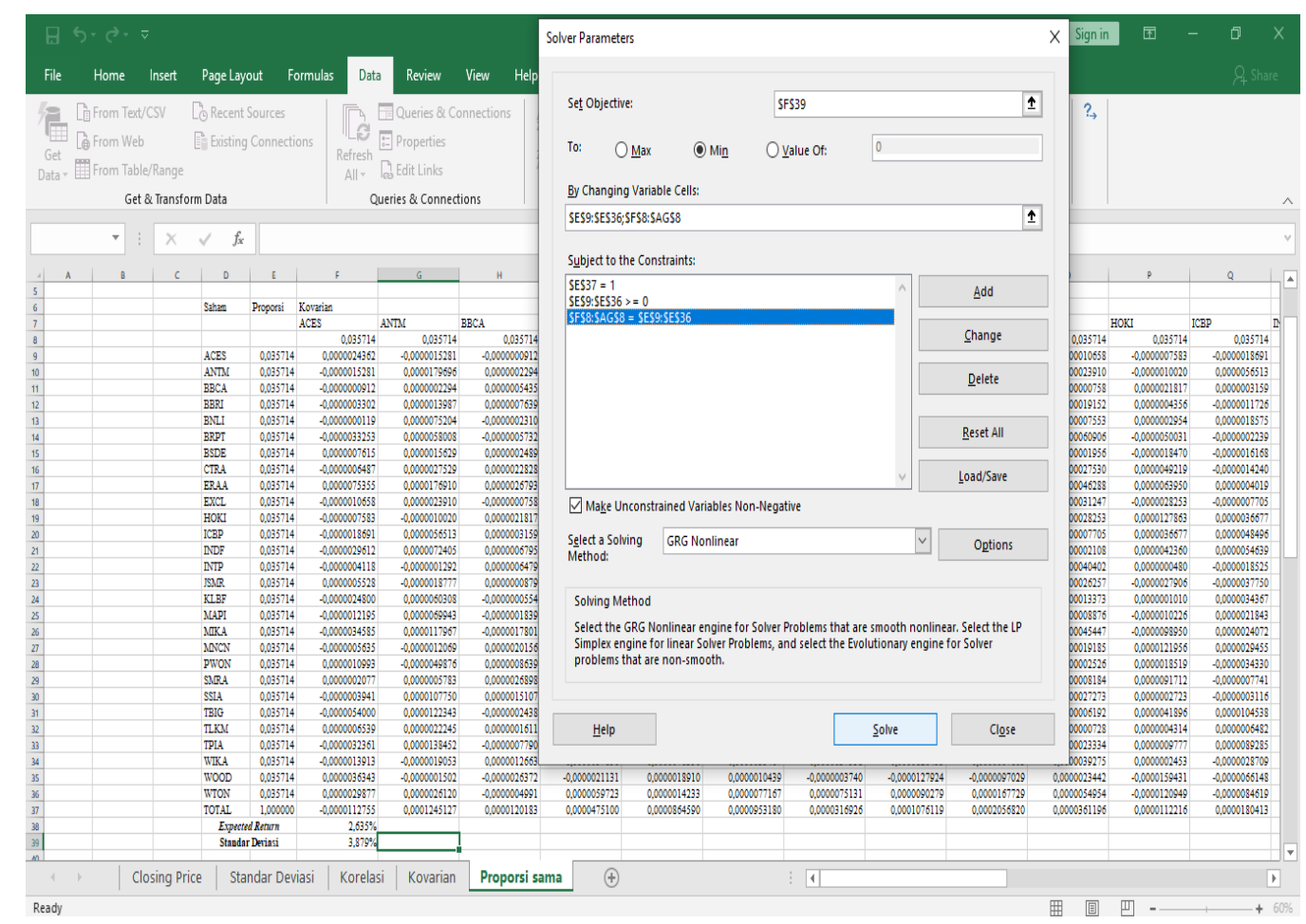

Gambar 1. Penyelesaian Menggunakan Program Solver

Sumber: Data diolah, 2019

Gambar 1. menunjukkan pengaturan pada jendela Solver dengan cara membuka aplikasi program Solver pada Microsoft Excel, kemudian muncul tampilan program Solver tersebut. Pada kolom set objective, masukkan cells nilai risiko portofolio saat menggunakan proporsi yang sama. Dalam meminimumkan risiko portofolio tersebut, dapat memilih menu "min" pada sub menu "to". Selanjutnya pada kotak "by changing variable cells" dapat dimasukan nilai kolom proporsi (Wi) dan baris proporsi (Wj) ke dua puluh delapan saham yang menjadi kandidat portofolio. Ini bertujuan untuk mengubah proporsi dana yang sama pada setiap saham menjadi proporsi yang optimal dengan batasan - batasan yang dapat di masukkan ke kotak "subject to the coustraints" antara lain, jumlah proporsi ( $\Sigma \mathrm{Wi}$ ) harus sama dengan satu, nilai proporsi (Wi) harus lebih besar atau sama dengan nol, serta nilai baris proporsi (Wj) dan kolom proporsi (Wi) harus sama.

Perhitungan expected return dan risiko portofolio menggunakan kovarian antar saham kandidat portofolio optimal dengan proporsi yang optimal dari aplikasi program Solver dapat dilihat pada Tabel 5, yaitu: 
Tabel 5.

Expected Return dan Risiko Portofolio dengan Menggunakan Proporsi Optimal

\begin{tabular}{llllll}
\hline No & Kode Saham & Proporsi & No & Kode Saham & Proporsi \\
\hline 1 & ACES & $11,458 \%$ & 15 & JSMR & $0,000 \%$ \\
2 & ANTM & $0,000 \%$ & 16 & KLBF & $0,000 \%$ \\
3 & BBCA & $0,000 \%$ & 17 & MAPI & $0,000 \%$ \\
4 & BBRI & $0,000 \%$ & 18 & MIKA & $0,000 \%$ \\
5 & BNLI & $0,000 \%$ & 19 & MNCN & $0,000 \%$ \\
6 & BRPT & $0,000 \%$ & 20 & PWON & $33,071 \%$ \\
7 & BSDE & $0,000 \%$ & 21 & SMRA & $0,000 \%$ \\
8 & CTRA & $0,000 \%$ & 22 & SSIA & $0,000 \%$ \\
9 & ERAA & $0,000 \%$ & 23 & TBIG & $9,541 \%$ \\
10 & EXCL & $0,000 \%$ & 24 & TLKM & $0,000 \%$ \\
11 & HOKI & $2,539 \%$ & 25 & TPIA & $0,000 \%$ \\
12 & ICBP & $26,947 \%$ & 26 & WIKA & $2,760 \%$ \\
13 & INDF & $0,000 \%$ & 27 & WOOD & $13,684 \%$ \\
14 & INTP & $0,000 \%$ & 28 & WTON & $0,000 \%$ \\
Expected Return & & & & $\mathbf{1 , 8 0 6 \%}$ \\
Standar Deviasi & & & & $\mathbf{0 , 7 0 5 \%}$ \\
\hline
\end{tabular}

Sumber: Data diolah, 2019

Tabel 5. menunjukkan dari 28 saham kandidat portofolio optimal, diperoleh 7 saham yang layak menjadi anggota portofolio optimal dengan saham PWON yang memiliki proporsi dana tertinggi sebesar 33,071 persen. Ketujuh anggota portofolio optimal tersebut terdiri dari saham ACES, HOKI, ICBP, PWON, TBIG, WIKA, dan WOOD dengan proporsi masing - masing dana yang diinvestasikan sebesar 11,458 persen, 2,539 persen, 26,947 persen, 33,071 persen, 9,541 persen, 2,760 persen, dan 13,684 persen yang memberikan expected return sebesar 1,806 persen dengan tingkat risiko sebesar 0,705 persen.

Berdasarkan hasil perhitungan dan analisis yang telah dilakukan memberikan hasil bahwa dari 28 saham kandidat portofolio yang membentuk portofolio optimal menggunakan model Markowitz periode Februari - September 2019 menghasilkan 7 saham yang layak menjadi anggota portofolio optimal. Aplikasi program Solver sangat membantu menentukan proporsi dana optimal masing - masing saham kandidat portofolio optimal. Tujuh anggota portofolio optimal dengan proporsi alokasi dana masing - masing yaitu saham ACES 11,458 persen, HOKI 2,539 persen, ICBP 26,947 persen, PWON 33,071 persen, TBIG 9,541 persen, WIKA 2,760 persen, dan WOOD 13,684 persen yang memberikan expected return portofolio sebesar 1,806 persen dengan tingkat risiko portofolio sebesar 0,705 persen.

Perbandingan investasi pada portofolio menggunakan proporsi dana sama dengan investasi pada portofolio menggunakan proporsi dana optimal memiliki perbedaan yang terlihat pada beban risiko yang ditanggung investor dan besarnya expected return yang diperoleh investor. Portofolio menggunakan proporsi dana sama menghasilkan expected return portofolio sebesar 2,635 persen, sedangkan portofolio menggunakan proporsi dana optimal menghasilkan expected return portofolio sebesar 1,806 persen. Expected return portofolio yang diperoleh investor menurun sebesar 0,829 persen. Portofolio menggunakan proporsi dana sama 
menghasilkan tingkat risiko portofolio sebesar 3,879 persen, sedangkan portofolio menggunakan proporsi dana optimal menghasilkan tingkat risiko portofolio sebesar 0,705 persen. Tingkat risiko yang ditanggung investor menurun sebesar 3,174 persen. Perbandingan ini menunjukkan bahwa expected return portofolio menggunakan proporsi optimal tidak jauh berbeda dengan proporsi dana sama dan tingkat risiko portofolio yang ditanggung lebih kecil saat menggunakan proporsi dana optimal dibandingkan dengan proporsi dana sama. Hal ini tentunya sangat membantu investor untuk memilih saham ketika akan berinvestasi pada saham indeks IDX80.

Perbandingan expected return dan risiko antara saham individual, portofolio sebelum Solver, dengan portofolio setelah Solver dapat dilihat pada Gambar 2, yaitu:

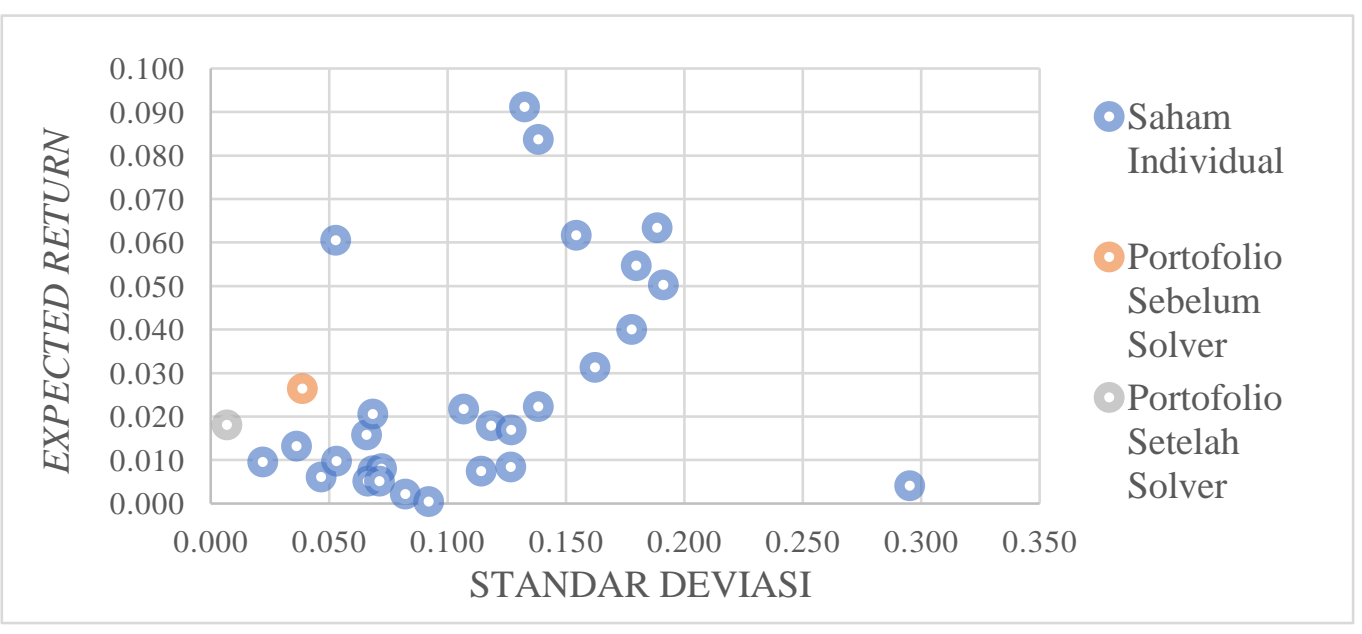

\section{Gambar 2. Perbandingan Expected Return dan Risiko Antara Saham Individual dengan Portofolio}

Sumber: Data diolah, 2019

Gambar 2. memperlihatkan perbandingan expected return dan risiko antara saham individual dengan portofolio. Saham individual menghasilkan expected return dan risiko yang beragam. Hal tersebut menunjukkan bahwa portofolio memberikan hasil kombinasi expected return tertentu dengan tingkat risiko yang rendah. Ini mengindikasikan bahwa diversifikasi dengan membentuk portofolio optimal terbukti dapat mengurangi tingkat risiko dalam suatu investasi dibandingkan dengan menginvestasikan seluruh dana pada satu saham yang memiliki expected return rendah dengan tingkat risiko tinggi. Portofolio yang dibentuk menggunakan model Markowitz sangat cocok untuk investor yang tidak menyukai risiko (risk averse) karena terlihat pada Gambar 2 bahwa portofolio memberikan tingkat risiko paling rendah dari saham individual lainnya.

Hasil dari penelitian ini memberikan implikasi teoritis yang menyatakan bahwa saham indeks IDX80 dapat digunakan untuk membentuk portofolio optimal dengan model Markowitz. Portofolio yang terbentuk sebagai bentuk dari diversifikasi investasi terbukti membantu mengurangi risiko investasi dibandingkan berinvestasi hanya pada satu saham. Hasil tersebut juga menunjukkan 
bahwa portofolio yang terbentuk mampu memberikan tingkat return yang maksimal dengan risiko yang dapat diminimumkan sesuai dengan harapan investor. Hal ini sesuai dengan teori portofolio Markowitz dan juga memperkuat temuan temuan sebelumnya bahwa portofolio model Markowitz hanya berdasarkan pada preferensi investor terhadap return dan risiko masing - masing investasi. Aplikasi program Solver yang digunakan semakin membantu investor dalam menentukan pilihan saham untuk diinvestasikan yang dapat memberikan return dan risiko sesuai harapan investor.

Hasil dari penelitian ini memberikan implikasi praktis bahwa investor dengan tipe risk averse (investor yang tidak menyukai risiko tinggi) yang ingin membentuk portofolio saham optimal cocok untuk memilih saham indeks IDX80. Pembentukan portofolio ini mengisyaratkan expected return portofolio sebesar 1,806 persen dengan tingkat risiko portofolio sebesar 0,705 persen. Adapun 7 saham perusahaan yang membentuk portofolio optimal yaitu saham ACES, HOKI, ICBP, PWON, TBIG, WIKA, dan WOOD yang dapat dipilih sebagai sebuah portofolio untuk membuat keputusan investasi mendatang.

\section{SIMPULAN}

Penentuan pembentukan portofolio optimal pada saham indeks IDX80 menggunakan model Markowitz periode Februari - September 2019 menunjukkan bahwa terdapat 7 saham perusahaan yang menjadi portofolio optimal, yaitu saham ACES, HOKI, ICBP, PWON, TBIG, WIKA, dan WOOD. Proporsi dana akhir masing - masing saham indeks IDX80 yang menjadi anggota portofolio optimal adalah saham ACES 11,458 persen, HOKI 2,539 persen, ICBP 26,947 persen, PWON 33,071 persen, TBIG 9,541 persen, WIKA 2,760 persen, dan WOOD 13,684 persen. Expected return portofolio yang diperoleh dari penentuan portofolio optimal menggunakan program Solver periode Februari - September 2019 sebesar 1,806 persen dengan tingkat risiko portofolio sebesar 0,705 persen.

Bagi investor yang ingin berinvestasi pada indeks IDX80, dapat menginvestasikan dananya sesuai dengan portofolio optimal yang terbentuk dari saham - saham yang terdiri atas saham ACES dengan proporsi dana 11,458 persen, HOKI dengan proporsi dana 2,539 persen, ICBP dengan proporsi dana 26,947 persen, PWON dengan proporsi dana 33,071 persen, TBIG dengan proporsi dana 9,541 persen, WIKA dengan proporsi dana 2,760 persen, dan WOOD dengan proporsi dana 13,684 persen yang memberikan tingkat return portofolio sebesar 1,806 persen dan risiko portofolio sebesar 0,705 persen. Investor juga disarankan tetap melakukan mengawasan karena portofolio ini tidak selamanya menjadi portofolio optimal.

Bagi peneliti lainnya yang akan melakukan penelitian sejenis agar dapat membandingkan model Markowitz dengan model lainnya untuk mengetahui apakah terdapat perbedaan hasil dalam pembentukan portofolio optimal. 


\section{REFERENSI}

Afriana, Titin., Tarno., dan S. (2017). Analisis Pembentukan Portofolio pada Perusahaan yang Terdaftar di LQ45 dengan Pendekatan Metode Markowitz Menggunakan Gui Matlab. Jurnal Gaussian, 6(2), 251-260.

Alaoui, Abdelhamid Hamidi., Jawad Abrache., Samir Aguenaou., \& N. N. (2015). Risk Optimization of the CNSS Portfolio Using a Return Constrained Markowitz Model. International Journal of Sciences: Basic and Applied Research (IJSBAR), 20(2), 383-389.

Azizah, Lutfi Hidayatul., Topowijono., dan S. S. (2017). Analisis Investasi Portofolio Optimal Saham Syariah dengan Menggunaan Model Markowitz dan Single Index Model (Studi Pada Saham Perusahaan yang Terdaftar di Jakarta Islamic Index (JII) Periode Desember 2012- Mei 2015). Jurnal Administrasi Bisnis (JAB), 42(1), 11-20.

Bhullar, Pritpal Singh., \& Gupta, P. K. (2016). Expected and Realized Stock Returns: Evidence From India. Asian Journal of Empirical Research, 6(11), 270-278.

Eka Pratiwi, A., Dzulkirom, M., \& Farah Azizah, D. (2014). Analisis Investasi Portofolio Saham Pasar Modal Syariah Dengan Model Markowitz Dan Model Indeks Tunggal. Jurnal Administrasi Bisnis, 17(1), 1-10.

Hartono, J. (2017). Teori Portofolio dan Analisis Investasi (Kesebelas). Yogyakarta: BPFE.

Hermuningsih, S. (2012). Pengantar Pasar Modal Indonesia (I). Yogyakarta: UPP STIM YKPN.

Iqbal, J., Sandhu, M. A., Amin, S., \& Manzoor, A. (2019). Portfolio Selection and Optimization through Neural Networks and Markowitz Model: A Case of Pakistan Stock Exchange Listed Companies. Review of Economics and Development Studies, 5(1), 183-195.

Ivanova, M., \& Dospatliev, L. (2017). Application of Markowitz Portfolio Optimization on Bulgarian Stock Market From 2013 to 2016. International Journal of Pure and Applied Mathematics, 117(2), 291-307.

Jones, C. P. (2004). Investments: Analysis and Management. America: Library of Congress Cataloging in Publication Data.

Khaoula, Farhat., \& Slaheddine, H. (2014). Emerging Markets and International Portfolio Optimization. International Journal of Management Sciences and Business Research, 3(7), 20-30.

Kulali, I. (2016). Portfolio Optimization Analysis with Markowitz Quadratic MeanVariance Model. European Journal of Business and Management, 8(7), 7379.

Latulanit, Kirana Amalia., Moh. Amin., dan M. C. M. (2018). Analisis Penentuan 
Ni Kadek Arista Dewi, Pembentukan Portofolio Optimal...

Portofolio Optimal dengan Menggunakan Model Markowitz pada Perusahaan Sektor Perbankan yang Terdaftar dalam Indeks LQ45 di Bursa Efek Indonesia. E-JRA, 7(6), 27-41.

Lee, H. S., Cheng, F. F., \& Chong, S. C. (2016). Markowitz portfolio theory and capital asset pricing model for Kuala Lumpur stock exchange: A case revisited. International Journal of Economics and Financial Issues, 6(3), 5965 .

London, A., Gera, I., \& Bánhelyi, B. (2018). Markowitz portfolio selection using various estimators of expected returns and filtering techniques for correlation matrices. Acta Polytechnica Hungarica, 15(1), 217-229

Maf'ula, Z., Ragil, S., Zahroh, H., Fakultas, Z. A., \& Adiministrasi, I. (2018). PORTOFOLIO OPTIMAL DENGAN PENERAPAN MODEL MARKOWITZ SEBAGAI DASAR KEPUTUSAN INVESTASI (Studi Pada Perusahaan Yang Tergabung Dalam Indeks LQ-45 Tahun 2014). In Jurnal Administrasi Bisnis (JAB), 63(1), 17-23.

Mahayani, N. P. M., \& Suarjaya, A. A. G. (2019). PENENTUAN PORTOFOLIO OPTIMAL BERDASARKAN MODEL MARKOWITZ PADA PERUSAHAAN INFRASTRUKTUR DI BURSA EFEK INDONESIA. $E$ Jurnal Manajemen Universitas Udayana, 8(5), 3057-3085.

Maryani, E. (2015). Analisis Pembentukan Portofolio Saham Optimal Menggunakan Model Indeks Tunggal dan Model Markowitz (Studi Kasus pada Saham BUMN yang Terdaftar di Bursa Efek Indonesia). Jom FEKON, 2(2), 1-14.

Mitra, A. (2014). Comparison of Sensex and Nifty Equities Using Markowitz Theory. International Journal of Economics, Commerce and Management, 2(2), 1-15.

Natalia, Eugina., Darminto., dan M. . W. E. N. (2014). Penentuan Portofolio Saham yang Optimal dengan Model Markowitz Sebagai Dasar Penetapan Investasi Saham (Studi pada Perusahaan Food and Baverage yang Terdaftar di Bursa Efek Indonesia Tahun 2012). Jurnal Administrasi Bisnis (JAB), 9(1), 1-9.

Nazir, M. (2014). Metode Penelitian. Bogor: Ghalia Indonesia.

Paudel, D. R. B., \& Koirala, S. (2006). Application of Markowitz and Sharpe Models in Nepalese Stock. Journal of Nepalese Business Studies, 3(1), 18-35.

Pracanda, S., \& Abundanti, N. (2017). PEMBENTUKAN PORTOFOLIO OPTIMAL DENGAN MENGGUNAKAN MODEL MARKOWITZ PADA SAHAM INDEKS IDX30 DI BURSA EFEK INDONESIA. E-Jurnal Manajemen Universitas Udayana, 6(2), 802-829.

Radović, M., Radukić, S., \& Njegomir, V. (2018). The Application of the Markowitz's Model in Efficient Portfolio Forming on the Capital Market in the Republic of Serbia. Economic Themes, 56(1), 17-34. 
Ramadhan, Rahadian Dwi., Siti Ragil Handayani., dan M. G. E. (2014). Analisis Pemilihan Portofolio Optimal dengan Model dan Pengembangan dari Portofolio Markowitz (Studi pada Indeks BISNIS-27 di Bursa Efek Indonesia periode 2011 - 2013). Jurnal Administrasi Bisnis (JAB), 14(1), 1-10.

Rifaldy, A., \& Sedana, I. (2016). OPTIMASI PORTOFOLIO SAHAM INDEKS BISNIS 27 DI BURSA EFEK INDONESIA (PENDEKATAN MODEL MARKOWITZ). E-Jurnal Manajemen Universitas Udayana, 5(3), 16571689.

Rodrigues, Joel Allen., \& S. B. (2018). A Study on Risk and Return in Building Optimal Portfolio Using Markowitz Model and Its Relevance in Current Scenario. International Journal of Advanced Research and Development, 3(2), 196-200.

Septyanto, D., \& Kertopati, B. (2014). Analisa Pembentukan Portofolio Dengan Menggunakan Model Markowitz dan Single Index Model Pada Saham Yang Masuk Dalam Indeks LQ45 Di Bursa Efek Indonesia Tahun 2009-2013. Finance and Banking Journal, 16(2), 140-156.

Setyawati, N. P. E. C., \& Sudiartha, G. M. (2019). PEMBENTUKAN PORTOFOLIO OPTIMAL MENGGUNAKAN MODEL MARKOWITZ. EJurnal Manajemen Universitas Udayana, 8(7), 4213-4238.

Shao, Shuai., Yang, Li-qun., Zhang, Yuan-biao., \& Meng, Z. (2016). A Modified Markowitz Multi-Period Dynamic Portfolio Selection Model Based on the LDIW-PSO. International Journal of Economics and Finance, 8(1), 90-98.

Solanki, A. H. (2014). Portfolio Selection Process through Markowitz Model. Indian Journal of Applied Research, 4(8), 356-358.

Suresh, A.S., \& H. N. (2017). Comparison of Returns and Risk Using Markowitz and Sharpe's Model. International Journal of Management and Commerce Innovations, 5(1), 806-813.

Tandelilin, E. (2010). Portofolio dan Investasi (Pertama). Yogyakarta: Kanisius.

Wahyuliantini dan Suarjaya. (2015). Pengaruh Harga Saham, Volume Perdagangan Saham, dan Volatilitas Return Saham pada BID - ASK SPREAD. Jurnal Manajemen, Strategi Bisnis Dan Kewirausahaan, 9(2), 146-155.

Yunita, I. (2018). Markowitz Model dalam Pembentukan Portofolio Optimal (Studi Kasus pada Jakarta Islamic Index). Jurnal Manajemen Indonesia, 18(1), 7785 .

Zubir, Z. (2011). Manajemen Portofolio (Penerapannya Dalam Investasi Saham). In Jakarta: Salemba Empat. 